\title{
Isolation and Identification of Bacteriocin-producing Bacillus Strain Isolated from the Gastrointestinal Tract of Indonesian Native Chicken (Gallus domesticus)
}

\author{
C Hanim ${ }^{1, *}$, V A Cahya ${ }^{2}$, L M Yusiati ${ }^{1}$ and A Kurniawati ${ }^{1}$ \\ ${ }^{1}$ Department of Animal Nutrition, Faculty of Animal Science, Universitas Gadjah Mada. Fauna Street No. 3, Sleman, \\ Yogyakarta 55281, Indonesia \\ ${ }^{2}$ Master Program in Faculty of Animal Science, Universitas Gadjah Mada. Fauna Street No. 3, Sleman, Yogyakarta \\ 55281, Indonesia \\ *Corresponding author. Email: c.hanim@ugm.ac.id
}

\begin{abstract}
This research aimed to obtain Bacillus bacteria from the gastrointestinal tract (GIT) of native Indonesian chicken (Gallus domesticus) for bacteriocin production purposes against Escherichia coli. Bacillus bacteria were isolated from GIT (duodenum, jejunum, and ileum) on Trypticase Soya Agar (TSA+5\% NaCl). The dilution was heated at $80^{\circ} \mathrm{C}$ for $20 \mathrm{~min}$ to kill other bacteria and induced Bacillus spore. Screening method based on the ability to against pathogens, then microbiological and biochemical characteristics. Inhibition test against pathogen using a well diffuse method. Thirteen Bacillus isolates then continued for testing against Escherichia coli FNCC 0091 for bacteriocin production purposes. Biochemical identification using conventional identification. The selected Bacillus bacteria, which had the highest inhibition zone, were isolates 2, 3B, and 11A (23.7, 18.6, and $19.9 \mathrm{~mm})$. Biochemical and microbiological identification revealed that the isolate 2 isolated from duodenum was mixed culture (Bacillus subtilis, and Bacillus sp.), isolate 3B isolated from jejunum was mixed culture (Bacillus subtilis, Bacillus sp., and Bacillus sp.) and isolate 11A isolated from ileum was pure culture (Bacillus subtilis). All isolates were identified as rod-shaped, Gram-positive, aerobic, endospore-forming bacteria, and produced catalase.
\end{abstract}

Keywords: Bacteriocin, Bacillus, Gallus domesticus, Gastrointestinal digestive tract, Isolation and Identification.

\section{INTRODUCTION}

Escherichia coli is the bacteria which typically present in chicken gastrointestinal tract (GIT). This bacteria nearly always caused a septicemic bacterial infection. The pathogenic diseases caused by these bacteria mostly happen when the chickens were stressed, and its immune system was down. Escherichia coli could multiply and cause a systemic infection that typically resulted in mortality and gross lesions characterized by the accumulation of a fibrino-purulent exudate [1]. The use of synthetic antibiotics added in feed or water is one of many ways to prevent and control the disease caused by Escherichia coli. However, the continued feeding chicken with synthetic antibiotic at sub-therapeutic levels has created concerns about the extent to which usage increases the possibilities of antibiotic residue in meat, the development of antibiotic-resistant bacteria, imbalance of beneficial, healthy gut flora, and a reduction in the ability to cure bacterial infections [2]. The residues of amoxicillin as much as $16.92-152.62 \mu \mathrm{g} / \mathrm{kg}$ in liver and $45.38-60.55 \mu \mathrm{g} / \mathrm{kg}$ in breast meat in broiler chickens and layer chicken in Bangladesh [3]. Increased awareness of the potential problems associated with the use of antibiotics has stimulated research efforts to identify alternatives to their use as feed additives. Among of these alternatives, probiotics have received much attention as the most promising substitute to infeed antibiotics and for improving animal productivity [2]. Bacteria from genus Bacillus are widely known as the producer of bacteriocin as antimicrobial substances. Bacteriocin produced by Bacillus bacteria have broadspectrum [4] and could potentially be used in the feed industries as natural antibiotics for livestock feed [5].

In Indonesia, there are 31 types of local chickens with genotypic and phenotypic characteristics that differ from one species to another. One of these local chickens is the native chicken (Gallus domesticus), which is the result of domestication from partridge (Gallus gallus) [6]. Native chicken is maintained and fed 
conventionally without in-feed antibiotics. With conventional maintaining and antibiotics-free feed, it is expected that Bacillus bacteria can be isolated from its GIT. Bacteriocin-producing bacteria was isolated from feces of cattle (Bacillus subtilis strains CB 153 and CB 189) and chickens (B. subtilis MSC 156 and Bacillus parabrevis MSC 164). Moreover, the isolates were screened after determining the inhibitory activity against the pathogenic indicator Clostridium perfringens KCTC 3269 , and are believed to be potential probiotics in the livestock industry [2]. The purpose of this study was to isolate and identify the bacteriocin-producing Bacillus bacteria with antagonistic activities against Escherichia coli from native chicken (Gallus domesticus), which maintained conventionally and to develop a potential candidate for probiotic use in the chicken as an alternative natural antibiotic.

\section{MATERIAL AND METHODS}

\subsection{Material}

Bacillus bacteria were isolated from GIT (duodenum, jejunum, and ileum) and obtained from native Indonesian chicken (Gallus domesticus), which maintained in a conventional farm. Trypticase Soya Agar (TSA $+5 \% \mathrm{NaCl})$ media to isolate the Bacillus bacteria and indicator organism (Escherichia coli FNCC 0091) were obtained from the Food and Nutrition Culture Collection (FNCC) Universitas Gadjah Mada. The tools used in this study, such as a set of tools to grow and to identify the bacteria. Spectrophotometer (Genesys $20^{\mathrm{TM}}$ ), centrifuge type 5810R (Eppendorf囚), vortex mixer model VM$1000,1.5 \mathrm{~mL}$ safe lock tube, laminar airflow, autoclave, calipers, and analytic scale.

\subsection{Methods}

\subsubsection{Isolation of Bacillus Bacteria.}

Bacillus bacteria were isolated from native chicken GIT [7] with modification in the media. Chicken intestines were cut $(1 \mathrm{~cm})$ according to each part (duodenum, jejunum, and ileum). Then, the sample were placed in a sterile centrifuge tube which contains $\mathrm{NaCl}$ physiological, then centrifuged $3000 \mathrm{rpm}$ for 10 minutes to get the pellets. The pellet was taken and diluted up to $10^{-6}$, then $1 \mathrm{ml}$ solution was heated at a temperature of $80^{\circ} \mathrm{C}$ for 20 minutes to turn off the other bacteria and induce the spores of the Bacillus. Next, $1 \mathrm{ml}$ of the solution poured onto $\mathrm{TSA}+\mathrm{NaCl} 5 \%$, which is already solid, then the incubation carried out for 48 hours. Each colony that grew and has a different appearance is taken and carried out for purification using the method of streaks (streak plate) for three times. The result of isolation is stored slant or NB broth at $4{ }^{\circ} \mathrm{C}$ (refrigerator) for further testing.

2.2.2. Selection of Antimicrobial Activity Produced by Isolates Against Escherichia coli.
The antimicrobial activity assay using a welldiffused method [8] with modification in well diameter $(5 \mathrm{~mm})$. A total of $50 \mu \mathrm{L}$ indicator organisms (Escherichia coli) dripped on to solid TSA media then swabbed evenly using a sterile cotton swab, and then 5 $\mathrm{mm}$ well was made using a cork borer. Each well was dripped as much $50 \mu \mathrm{L}$ of isolate; then, the incubation period lasted for 24 hours at $37^{\circ} \mathrm{C}$. The presence of a clear zone around the well indicated that the bacteria produced the bacteriocin to inhibit the indicator organism's growth. Clear zone diameter was measured by calipers. The next step used the isolates that have the broader clear zone.

\subsubsection{Identification of superior isolates.}

The identification of selected isolates was determined by the conventional method refers to Bergey's Manual of Systematic Bacteriology [9]. The identification includes microbiological tests, biochemical tests, and catalase production test.

\section{RESULT AND DISCUSSION}

\subsection{Isolation and Selection of antimicrobial activity produced by Bacillus bacteria against Escherichia coli}

The source of the bacteria Bacillus was from the native chicken's digestive tract, a part of the intestine (duodenum, jejunum, and ileum). Furthermore, the isolates were selected to obtain superior isolates, which produced the most extensive clear zone. Bacteriocinproducing bacteria namely $B$. subtilis MSC 156 and Bacillus parabrevis MSC 164 were isolated from chickens' feces. Then, the isolates were screened after determining the inhibitory activity against the pathogenic indicator Clostridium perfringens KCTC 3269 [2]. Table 1 shows the measurement of the inhibition of each isolate against Escherichia coli.

Table 1. The selection of superior isolates based on the inhibition of Escherichia coli

\begin{tabular}{|c|c|}
\hline Codes of isolates & Clear zone diameter $(\mathrm{mm})$ \\
\hline 1A (duodenum) & 11.7 \\
\hline 2 (duodenum) & 23.7 \\
\hline 3A (јејепит) & 4.7 \\
\hline 3B (jejenum) & 18.6 \\
\hline 3C (jejenum) & 3.7 \\
\hline 4A (jejenum) & - \\
\hline 4B (jejenum) & - \\
\hline 9A (jejenum) & 4.3 \\
\hline 9B (jејепит) & - \\
\hline 10 (јејепит) & 5.4 \\
\hline 11A(ileum) & 19.9 \\
\hline 11B(ileum) & 8.6 \\
\hline 12 (ileum) & 9.7 \\
\hline
\end{tabular}

The results showed that the broadest clear zone found on the isolates code of 2 (duodenum isolate), the 3B (jejunum isolate), and the 11A (ileum isolate). Each 
isolate has an average value of the clear zone by 23.7 , 18.6 , and $19.9 \mathrm{~mm}$. The clear zone diameter of isolate 2 catalase-positive, and strict aerobic, rod-shaped bacterium. Based on comparisons of their characteristics

Table 2. The result of identification isolates 2, 3B and $11 \mathrm{~A}$

\begin{tabular}{clccl}
\hline Code of bacteria & Gram Staining & Morphological form & Catalase test & Species identification \\
\hline 2 & Gram positive & Rod & + & Bacillus subtilis, Bacillus \\
sp. & & Bacillus sp., Bacillus sp., \\
3B & Gram positive & Rod & + & Bacillus sp. \\
11A & Gram positive & Rod & + & Bacillus subtilis \\
\hline
\end{tabular}

with Bergey's manual and the results of the API test

Table 3. The result of biochemical and identification of isolates 2, 3B and 11A

\begin{tabular}{lccc}
\hline \multirow{2}{*}{ Substrate Type } & \multicolumn{3}{c}{ Code of isolates } \\
\cline { 2 - 4 } & 2 & $3 \mathrm{~B}$ & $11 \mathrm{~A}$ \\
\hline Glucose & + & + & + \\
Lactose & - & - & - \\
Mannitol & + & + & + \\
Maltose & + & + & + \\
Sucrose & + & + & + \\
Glucose 6\% & + & - & + \\
Ammilum & + & + & + \\
Nitric & + & + & + \\
Anaerob & - & - & - \\
condition & - & & - \\
Fat globule & - & - & - \\
Lesitinase & - & - & \\
\hline a + : positive & & & \\
b - : negative & & &
\end{tabular}

against Escherichia coli was higher than the previous research [10], which was $21.33 \pm 0.33 \mathrm{~mm}$. The clear zone of isolate $3 \mathrm{~B}$ and isolate $11 \mathrm{~A}$ also showed good results as seen in the clear zone diameter which was close to the results of the previous research [10]. Bacteria of the genus Bacillus had broad antimicrobial activity spectrum against various pathogenic bacteria of Gram-positive (Staphylococcus aureus, Streptococcus pyogenes, and Enterococcus faecalis) and Gramnegative (Escherichia coli, Pseudomonas aeruginosa, Klebsiella pneumonia, and Proteus vulgaris) [10] [11]. Antimicrobial compounds of bacteriocin inhibited the pathogenic bacteria cell walls forming, causing the cells would not able to develop and bring the pathogenic bacteria to the death phase [12]. Antimicrobial compounds produced by Bacillus bacteria were a strategy to maintain the balance of the population and reduce the population of competitors [13].

\subsection{Identification of superior isolates}

The selected bacteria, i.e., isolates $2,3 \mathrm{~B}$, and $11 \mathrm{~A}$, then identified by the biochemical and morphological tests. Catalase production assay was done to determine the isolates belong to the group of aerobic bacteria or anaerobic. Table 2 and 3 show the results of the identification of isolates $2,3 \mathrm{~B}$, and $11 \mathrm{~A}$.

Bacteriocin-producing bacteria selected from chickens' feces were characterized as a Gram-positive, (data not shown), the isolates were classified as $B$. subtilis [2].

\subsubsection{Gram Staining.}

Based on the results of the Gram staining, all isolates cells showed purple color, which showed these bacteria belonged to the Gram-positive bacteria. All isolates also produced spores in the middle of the cell. Genus Bacillus bacteria had a rod shape, Gram-positive bacteria, and produced spores [15]. When environmental conditions did not support growth, such as lack of nutrients, high or low temperature, $\mathrm{pH}$ conditions of acid or alkaline, it will lead to spores growth [5]. Figure 1 presents the results of the Gram stain.

Gram-positive bacteria had a thicker layer of peptidoglycan than Gram-negative. Gram-positive protein cell wall would denature with alcohol wash. Protein will become hard and rigid, the pores shrink, less permeability so that the purple complex of iodine crystal is maintained, thus, bacteria remain purple. The lipid structure of Gram-negative bacteria will dissolve during the alcohol wash; the cell wall would be enlarged, the permeability of the cell wall became large so that the color substance which had been absorbed was quickly released and the bacterial cell became colorless [15]. The cell of Gram-positive bacteria has a thick cell wall consisting of several layers of mucopeptide and two types of teichoic acid. The walls of the molecules of teichoic acid connect onto a layer mucopeptide and molecules of the teichoic acid link to the second mucopeptide and the cytoplasmic membrane [16].

\subsubsection{Catalase Production Assay.}

Based on the results of the catalase production assay, all isolates showed the presence of air bubbles when spilled with hydrogen peroxide $\left(\mathrm{H}_{2} \mathrm{O}_{2}\right)$. When colonies of bacteria were spilled with the hydrogen peroxide, the liberation of oxygen as gas can be seen. The air bubbles of oxygen $\left(\mathrm{O}_{2}\right)$ are formed due to the Bacillus bacteria enzymes which able to break down $\mathrm{H}_{2} \mathrm{O}_{2}$ [15]. The catalase enzyme converts $\mathrm{H}_{2} \mathrm{O}_{2}$ into water $\left(\mathrm{H}_{2} \mathrm{O}\right)$ and oxygen $\left(\mathrm{O}_{2}\right)$, so that all isolates were categorized in positive catalase. Positive catalase indicated that all 
isolates of bacteria were aerobic or facultative anaerobic bacteria. The type of aerobic bacteria and facultative anaerobes could convert $\mathrm{H}_{2} \mathrm{O}_{2}$ using the superoxide dismutase enzyme, then will be broken down by the catalase enzyme. Obligate anaerobes bacteria did not have superoxide dismutase and catalase enzymes so that it could not be tolerated to the presence of oxygen [16]. Catalase enzyme in Bacillus subtilis was produced in the stationary phase, and the vegetative phase (spores). The production of the enzyme catalase in Bacillus bacteria is the mechanism to protect bacteria against oxidative stress. The presence of the enzyme catalase in Bacillus bacteria plays an important role, namely to protect bacteria against $\mathrm{H}_{2} \mathrm{O}_{2}$ that could damage the cells. The genes which code for the secretion of the enzyme catalase in Bacillus subtilis was the KatA [17].

\subsubsection{Determining The Superior Isolates.}

The species of Bacillus bacteria are determined by the phenotype based on the biochemical test, namely fermentation ability of different types of sugar and the substrate. All isolates were able to ferment glucose, but not able to ferment lactose. Bacillus subtilis could ferment glucose to produce acid but was not able to ferment lactose [18] [19]. Table 3 shows the results of the biochemical test and the identification of the species. The results showed that isolate 2 was identified as mix culture between Bacillus subtilis and Bacillus sp., isolates 3B identified as mix culture of three Bacillus $s p$. and isolate 11 was identified as the pure culture of Bacillus subtilis.

The isolation and identification results showed that the digestive tract of native chicken contained the bacteria of the genus Bacillus. Bacillus bacteria were microbes that exist in the normal/healthy conditions of the digestive tract [20]. The Bacillus bacteria found in the digestive tract of the chicken are namely Bacillus subtilis, Bacillus pumilus, Bacillus lincheniformis, Bacillus clausii, Bacillus megaterium, and Bacillus firmus [21]. The presence of Bacillus bacteria in the digestive tract comes from the soil, feed, and drinking water consumed by the chicken. It could suppress the presence of a wide variety of pathogens, such as Salmonella typhimurium, Salmonella pullorum, Escherichia coli, Clostridium perfringens, Staphylococcus aureus, and Listeria monocytogenes [22]-[24]. Bacillus subtilis was GRAS (generally regarded as safe) and safe for consumption [25].

\section{CONCLUSION}

It can be concluded from this research that there are several $\mathrm{LAB}$ found in $\mathrm{A}$. nigrocincta, which also commonly found in other Apis species. Leuconostoc, Lactobacillus, and Bifidobacterium are proposed here as the core gut LAB of A. nigrocincta.

\section{REFERENCES}

[1] Winfree R, Aguilar R, Vázquez DP, LeBuhn G and Aizen MA 2009 Ecology 90 2068-2076 doi:10.1890/08-1245.1

[2] Goulson D, Nicholls E, Botias C and Rotheray $\begin{array}{lllll}\text { EL } & 2015 & \text { Science } & \mathbf{3 4 7} & 1255957\end{array}$ doi:10.1126/science. 1255957

[3] Akami M, Andongma AA, Zhengzhong C, Nan J, Khaeso K, Jurkevitch E, et al. 2019 PloS one 14(1) e0210109 doi:10.1371/journal.pone.0210109

[4] Gilliland SE 1990 FEMS Microbiol. Rev. 7(1-2) $175-88$ doi:10.1111/j.15746968.1990.tb04887.x

[5] Parichehreh S, Tahmasbi G, Sarafrazi A, et al. 2018 Apidologie 49430 doi:10.1007/s13592018-0569-z

[6] Vásquez A, Forsgren E, Fries I, Paxton RJ, Flaberg E, Szekely L and Olofsson TC 2012 $\begin{array}{llll}P l o S & \text { one } & \mathbf{7}(3) & \end{array}$ doi:10.1371/journal.pone.0033188

[7] Lombogia CA, Posangi J, Pollo HN, Tulung M and Tallei TE 2020a Scientifica Article ID 1609473, 8pp doi: 10.1155/2020/1609473

[8] Hadisoesilo S 2001 Biodiversitas 2(1) 123-128 doi:10.13057/biodiv/d020107.

[9] Lombogia CA, Tulung M, Posangi J and Tallei TE 2020b Open Micro J. 14 72-76 doi: 10.2174/1874285802014010072

[10] Tallei TE, Fatimawali, Pelealu JJ 2019 Data in Brief 25104190

[11] Kusumawaty D, Surtikanti HK, Hernawati and Tallei TE 2020 Data in Brief 29105299

[12] Fatimawali, Kepel BJ, Gani MA and Tallei TE 2020 Int. J. Microb. Article ID 1858732, 8pp doi: 10.1155/2020/1858732

[13] Lü X, Yi L, Dang J, Dang Y and Liu B 2014 Food Control 46 264-271

[14] Mazzolia R, Boscob F, Mizrahic I, Bayer EA and Pessione 2014 Biotech. Adv. 32(7) 12161236 doi:10.1016/j.biotechadv.2014.07.005

[15] Ellegaard KM, Tamarit D, Javelind E, Olofsson TC, Andersson SG and Vásquez A 2015 BMC genomics 16(1) 284 doi:10.1186/s12864-0151476-6

[16] Martinson VG, Danforth BN, Minckley RL, Rueppell O, Tingek S, Moran NA 2011 Mol. Ecol. 20 619-628

[17] Asenjo F, Olmos A, Henríquez-Piskulich P, Polanco V, Aldea P, Ugalde JA and Trombert AN 2016 PeerJ 4 e1950 doi:10.7717/peerj.1950 
[18] Ming L, Zhang Q, Yang L and Huang JA 2015 Int. J. Clinical Exp. Med. 8(4) 5806-5811

[19] Linjordet MT 2016 A Comparative Analysis of Lactic Acid Bacteria Isolated from Honeybee Gut and Flowers, with focus on Phylogeny and Plasmid. Master's theses Norwegian: Norwegian University of Life Sciences

[20] Filannino P, Di Cagno R, Addante R, Pontonio E and Gobbetti M 2016 Appl. Environ. Microbiol. $\quad$ 82(23) 6899-6911 doi: 10.1128/AEM.02194-16.

[21] Carina Audisio M, Torres MJ, Sabaté DC, Ibarguren C and Apella MC 2011 Microbiol. Res. 166(1) $1-13$ doi:10.1016/j.micres.2010.01.003

[22] Mathialagan M, Edward YSJT, David PMM, Senthilkumar M, Srinivasan MR and Mohankuma S 2018 Int. J. Curr. Microbiol. App. Sci 7(4) 894-906

[23] Wang C, Huang Y, Li L, Guo J, Wu Z, Deng Y et al. 2018 Int. J. Syst. Evol. Microbiol. 68(3) 703-708 doi:10.1099/ijsem.0.002538

[24] Olofsson TC, Butler È, Markowicz P, Lindholm C, Larsson L and Vásquez A 2014 Int. Wound J. 668-679 doi: 10.1111/iwj.12345

[25] Honey Chandran C and Keerthi TR 2018 FEMS Microbiol. Lett. 365(4) doi: 10.1093/femsle/fnx285.

[26] Tajabadi N, Mardan M, Manap MYA, Shumaimi M, Meimandipour A and Nateghi L 2011 Apidologie 42 642-649

[27] Parichehreh S, Tahmasbi G, Sarafrazi A, Imani S and Tajabadi 2018 Apidologie 49:3 430-438

[28] Bottacini F, Milani C, Turroni F, Sánchez B, Foroni E, Duranti S et al. 2012 PloS one 7(9) e44229 doi:10.1371/journal.pone.0044229

[29] Nomoto R, Takano S, Tanaka K, Tsujikawa Y, Kusunoki H and Osawa R 2017 Biosci. Microb. Food Health 36(3) 91-99 doi:10.12938/bmfh.16-027

[30] Collado MC, González A, González R, Hernández M, Ferrús MA and Sanz Y 2005 Int. J. Antimicrob. Agents 25(5) 385-91

[31] Tanhaieiana A, Hadi M, Farajollah S, Ahmadia S and Mamarabadia M 2018 Microbial Pathogenesis 125 51-59

[32] Shin JM, Gwak JW, Kamarajan P, Fenno JC, Rickard AH and Kapila YL 2016 J. App. Microbiol. $\quad \mathbf{1 2 0}(6) \quad 1449-1465$ doi:10.1111/jam.13033

[33] Volzing K, Borrero J, Sadowsky MJ and Kaznessis YN 2013 ACS Synth. Biol. 2(11) 643650. doi:10.1021/sb4000367

[34] Zendo T, Koga S, Shigeri Y, Nakayama J and Sonomoto K 2006 App. Env. Microb. 72(5) 3383-3389 doi:10.1128/AEM.72.5.33833389.2006

[35] Avand A, Akbari V and Shafizadegan S 2018 Iranian J. Biotech. 16(3) e1867 doi:10.21859/ijb.1867
[36] Tallei TE, Fatimawali, Sumual AM, Gani MA, Pollo GAV, Adam AA and Pelealu JJ 2020 IOP Conf. Ser. Mater. Sci. Eng.

[37] Yi YJ, Lim JM, Gu S, Lee WK, Oh E, Lee SM and Oh BT 2017 J. Microbiol 55(4) 296-303 doi: 10.1007/s12275-017-6642-x

[38] Masuda Y, Ono H, Kitagawa H, Ito H, Mu F, Sawa N, Zendo T and Sonomoto K 2011 App. Env. Microbiol. $\quad \mathbf{7 7 ( 2 2 )} \quad 8164-8170$ doi:10.1128/AEM.06348-11 